\title{
THE INDIGENOUS EARTHWORMS (MEGASCOLECIDAE: OLIGOCHAETA) OF LORD HOWE ISLAND
}

\author{
B. G. M. JAMIESON \\ Zoology Department, University of Queensland
}

\begin{abstract}
SUMMARY
The known indigenous earthworms of Lord Howe Island are restricted to the subfamily Megascolecinae. They are assignable to six genera with ten species, Diporochaeta plutelloides sp. n., Plutellus hutchingsae sp. n., Paraplutellus insularis Jamieson, and Pericryptodrilus nanus gen. et sp. n. (Tribe Perionychini), Eastoniella gen. n. with E. howeana and E. modesta spp. n. (Tribe Dichogastrini) and Spenceriella (Austroscolex) subgen. n., with $S$. (A.) howeana, S. (A.) difficilis, S. (A.) hollowayi and S. (A.) saundersi spp. $\mathrm{n}$., (Tribe Megascolecini). In addition to these 10 endemic species, the circummundane Amynthas diffringens Baird and the anthropochorous holarctic family Lumbricidae are recorded from the island. Diporochaeta and Spenceriella (Austroscolex) are otherwise restricted to Australia and (secondarily?) New Zealand, and Plutellus to Australia. Pericryptodrilus and Eastoniella are known only from the island but have strong Australian affinities. The earthworm fauna thus appears to be of Australian origin. Evidence for rifting of the Lord Howe Rise from Eastern Australia at $\sim 80$ million years before the present is noted but it is considered unlikely that the earthworm fauna dates from that period in view of catastrophic vulcanism on the island between $\sim 30$ and 8 million years before the present. The zoogeography and evolution of the earthworms is discussed and a tentative hypothesis of origin of the predominantly Oriental genus Pheretima s. lat. from an Australian precursor of Spenceriella is advanced.
\end{abstract}

\section{INTRODUCTION}

Lord Howe Island, $700 \mathrm{~km}$ NE of Sydney, Australia, at It. $31^{\circ} 31^{\prime} \mathrm{S}$, long. $158^{\circ} 04^{\prime} \mathrm{E}$, is one of several volcanic peaks on Lord Howe Rise, the others, with the exception of Ball's Pyramid $20 \mathrm{~km}$ away, being submerged. The Rise which joins the Coral Sea Platform in the north and the Campbell Plateau in the south on which New Zealand is situated, forms an easterly and northeasterly boundary of the Tasman Sea. The bed of the Tasman Sea is bisected by an extinct tectonic ridge (mid-ocean ridge), trending approximately north-west to south-east, the morphology of which is consistent with its having been the axis of origin of sea-floor spreading. Hayes and Ringis (1973) have brought the two oldest corresponding magnetic anomalies together ( 80 million years before the present), the one closest to the continental edge of east Australia, the other closest to the Lord Howe Rise, and state that because of the well developed magnetic pattern there is "not much uncertainty" as to the pre-rifted configuration of the two continental elements. Their reconstruction, bringing the Lord Howe Rise into contact with eastern Australia at $\mathbf{8 0}$ million years before the present, is of the greatest interest for zoogeography as it establishes that the primary faunistic affinities of the Lord Howe Island area must have lain with eastern Australia, of which it was a part. At that

Records of The Australian Museum, 1977, 30, 272-308, Figures 1-7. 